\title{
Gas exchange and chlorophyll $a$ fluorescence parameters of ornamental bromeliads ${ }^{(1)}$
}

\author{
KARINA GONÇALVES DA SILVA ${ }^{(2) *}$, EMERSON ALVES DA SILVA ${ }^{(2)}$, MAURICIO LAMANO FERREIRA ${ }^{(3)}$, SHOEY \\ KANASHIRO(2), PLÍNIO BARBOSA DE CAMARGO(4), ARMANDO REIS TAVARES(2)
}

\begin{abstract}
Gas exchange and chlorophyll $a$ fluorescence are widely used in physiological and ecological studies; however, few studies have used these techniques with ornamental plants. This study tested the potential contribution of gas exchange and chlorophyll $a$ fluorescence to evaluate the water and nutrients uptake by the tank and root system of epiphyte bromeliad Guzmania lingulata. For this purpose, we conducted an experiment with different water regime and another with different concentrations of nitrogen. The experiments were: 1 - Watering: Control (application of water into Tank and Root), Tank (watering into Tank), Root (watering Root) and Drought (water suspension during the 90 days of experimentation) and 2 - Nitrogen: Plants fertilized with Hoagland and Arnon nutrient solution exclusively into Tank or Root with nitrogen concentrations of control and 2.62 or $5.34 \mathrm{mMN}$ applied as urea. The $\mathrm{F}_{\mathrm{v}} / \mathrm{F}_{\mathrm{m}}$ ratio allowed comparing the treatments between experiments, demonstrating that Root and Tank both have the capacity to maintain G. lingulata photosynthetic activity and growth, while Drought treatment (water suspension) was the limiting factor for energy conversion efficiency of PSII. However, gas exchange was more permissive as a parameter for comparing treatments in the nitrogen experiment, providing important information about the general aspects of the photosynthetic process in the watering experiment. Both gas exchange and chlorophyll $a$ fluorescence can support the evaluation of $G$. lingulata physiological status and can be useful tools in ornamental horticultural studies.
\end{abstract}

Keywords: Bromeliaceae, nutrition, drought stress, IRGA, fluorometer.

\section{RESUMO}

Trocas gasosas e fluorescência da clorofila $a$ de bromélias ornamentais

Os parâmetros de trocas gasosas e fluorescência da clorofila a são amplamente utilizados em estudos fisiológicos e ecológicos, no entanto essas técnicas tem tido pouco destaque em estudos com plantas ornamentais. Neste estudo, foi testado o potencial de contribuição dessas técnicas para avaliação da absorção de água e nutrientes pelo tanque e sistema radicular da bromélia epífita Guzmania lingulata. Para tanto foram desenvolvidos experimentos com diferentes regimes hídricos e diferentes concentrações de nitrogênio. Os experimentos foram: 1 - Irrigação: Controle (aplicação de água no Tanque e Raiz), Tanque (regas no Tanque), Raiz (regas no substrato), Seca (suspensão hídrica durante os 90 dias de experimento) e o segundo as plantas foram submetidas a adubação com solução nutritiva de Hoagland and Arnon exclusivas no Tanque ou na Raiz nas concentrações de nitrogênio de $0.00,2.62$ ou $5.34 \mathrm{mM} \mathrm{N}$ aplicadas na forma de ureia. Nos dois experimentos a razão $F_{v} / F_{m}$ foi eficiente para comparação dos tratamentos, demonstrando que tanto a raiz como o tanque apresentam a capacidade de manter a atividade fotossintética e o crescimento de G. lingulata, sendo que o maior limitante para a eficiência de conversão de energia do PSII é a suspensão hídrica. Os parâmetros de trocas gasosas foram mais eficientes no experimento nutricional para comparação entre os tratamentos, porém forneceu importantes informações sobre o aspecto geral do processo fotossintético no experimento hídrico. Essas técnicas apresentam relevante contribuição para avaliação do cultivo de bromélia ornamental, podendo ser uma ferramenta incorporada nos estudos de horticultura.

Palavras-chave: Bromeliaceae, nutrição, déficit hídrico, IRGA, fluorômetro.

\section{INTRODUCTION}

Bromeliads are widely used in landscaping and interior decoration owing to the variety of shapes and colors of flowers, inflorescences and leaves and high durability of flowers. There is a marked use of plants from genera Aechmea, Alcantarea, Billbergia, Guzmana, Neoregelia, Pitcairnia and Vriesea (SOUZA and LORENZI, 2000).
Many Bromeliaceae species present a reservoir formation known as the tank. This structure is formed by the overlay of leaves, allowing water and organic matter to accumulate. Together with foliar trichomes, water uptake and nutritional uptake are guaranteed. In contrast, the roots of bromeliads display reduced function, acting only as an anchorage organ. These strategies are associated with plants that adapt to epiphytic habitats (CACH-PÉREZ et al., 2014). However,

DOI: http://dx.doi.org/10.14295/oh.v23i4.1064

${ }^{(1)}$ Received in 19/06/2017 and accepted in 17/11/2017

${ }^{(2)}$ Instituto de Botânica (IBt), São Paulo-SP, Brazil. *Corresponding author: karina.gs.bio@gmail.com

${ }^{(3)}$ Universidade Nove de Julho, Smart and Intelligent Cities Programme, São Paulo-SP, Brazil.

${ }^{(3)}$ Universidade de São Paulo, "Escola Superior de Agricultura Luiz de Queiroz", Piracicaba-SP, Brazil.

Licensed by CC BY 4.0 
this functional division between tank and roots has been questioned (PITA and MENEZES, 2002; SEGECIN and SCATENA, 2004; PROENÇA and SAJO, 2008), and the unknown uptake potential of the vegetative organs affects the management of water and nutrients in the context of bromeliad cultivation.

The fertilization of bromeliads varies greatly among producers. Producers in southeastern (67\%) and southern $(50 \%)$ Brazil provide fertilization on tank foliar and root. Out of producers in the southeast, $16 \%$ fertilize only the roots, while $17 \%$ only fertilize the tank. Out of producers in the south, 25\% fertilize a single organ (ANDRADE and DEMATTÊ, 1999). This diversity of fertilization management reflects the gaps of knowledge about the cultivation of bromeliads, thus physiological parameters as gas exchange and chlorophyll $a$ fluorescence could help to establish the method and levels of fertilization on ornamental bromeliads that represent the maximum biological efficiency of the plants.

Chlorophyll $a$ fluorescence and gas exchange are useful tools in vegetable studies, allowing the evaluation of plant development and responses to environmental stresses (LONG and BERNACCHI, 2003; MATTOS, 2006). These practices are widely used in ecological and physiological research (WOODRUFF et al., 2015; SHARKEY, 2016); however, their use in ornamental horticulture is infrequent, and the potential contribution of the techniques remains unexplored, especially for the cultivation of bromeliads. Gas exchange measurement and chlorophyll $a$ fluorescence are both fast and nondestructive, as they involve efficiently evaluating the conversion of light energy into organic molecules by the photosynthetic apparatus, as well as stimulating plant growth and the responses linked to environmental stresses that affect photosynthesis, such as water and the availability of nutrition (KRAUSE and WEIS, 1991; RAMOS TAMAYO et al., 2001).

Plant growth is closely related to the conversion of light energy into chemical energy by the photosynthetic process. The pigments of antenna absorb the light, and the excitation energy is transferred to the reaction centers of the PSII and PSI photosystems in the photosynthetic apparatus. Photosynthetic pigments, such as molecules of chlorophyll $a$, promote the transportation of electrons originated from water between the two photosystems in the reaction centers. Electron transport is responsible for NADPH production and formation of ATP. Subsequently, these molecules will be used for the reduction of carbon to carbohydrates in the Calvin Cycle. Moreover, growth is related to respiration that provides energy in the form of ATP and reduction power necessary for plant maintenance and growth, while intermediates of the tricarboxylic acid cycle provide the necessary carbon skeletons for the synthesis of cell and tissue components (TAIZ and ZEIGER, 2006; GIMENO et al., 2010). These processes can be measured by gas exchange analysis techniques and chlorophyll $a$ fluorescence, and the results will allow us to estimate the photosynthetic reactions from $\mathrm{CO}_{2}$ absorption and water vapor loss. The yield of chlorophyll fluorescence reveals the level of energy excitation in the pigment system, which controls photosynthesis. Using this measurement, we can estimate the inhibition or damage to the electron transfer process in PSII. $\mathrm{F}_{\mathrm{v}} / \mathrm{F}_{\mathrm{m}}$ ratio (potential quantum efficiency of PSII) is a widely used parameter of chlorophyll fluorescence, and it is used to estimate the maximum efficiency of PS II when all its reaction centers are opened (KRAUSE and WEIS, 1991; RAMOS TAMAYO et al., 2001; MATTOS, 2006).

This study aimed to evaluate $\mathrm{CO}_{2}$ exchange and fluorescence of chlorophyll $a$ as useful tools to analyze the physiological status of the epiphytic bromeliad Guzmana lingulata (L.) Mez, submitted to different regimes of irrigation and nitrogen nutrition.

\section{MATERIAL AND METHODS}

Seedlings of $G$. lingulata approximately six months of age were cultivated in black polyethylene containers (1.25 L) containing composted Pinus bark as substrate. The experiment was conducted in a greenhouse of the Instituto de Botânica, São Paulo State, Brazil. Average temperature of $20.7,30$ and $15.3{ }^{\circ} \mathrm{C}$ and average relative air humidity of $56,37.0$ and $40.3 \%$ were observed in the greenhouse at 30 , 60 and 90 days, respectively.

Two experiments were conducted. The first consisted of different water regimes with experimental design entirely randomized in the factorial $4 \times 3$, comprising four treatments and three time intervals (0, 30, 60 and 90 days). Control treatment received $200 \mathrm{~mL}$ of water on roots (substrate field capacity) and $20 \mathrm{~mL}$ into the tank (maximum capacity without overflow to the substrate). Tank treatment received no water on roots and $20 \mathrm{~mL}$ into the tank, while Root treatment received $200 \mathrm{~mL}$ of water on roots and no water into the tank. Drought treatment consisted of suspending water during the 90 days of experimental period. The second experimental design was entirely randomized in the factorial $2 \times 3 \times 3$ with $\mathrm{N}$ application on roots or into the tank. Three concentrations of $\mathrm{N}$ were used at three time intervals. Specifically, twice a week, half the plants received $20 \mathrm{~mL}$ of Hoagland and Arnon $n^{\circ} 1$ solution (1950) modified at concentrations of $0,2.62$ or $5.34 \mathrm{mM} \mathrm{N}$ as urea into the tank or on roots. The $\mathrm{pH}$ of solutions was adjusted to 5.8.

The plants of both experiments were analyzed after 30 , 60 and 90 days of experimentation for gas exchanges and chlorophyll $a$ fluorescence in three plants of each treatment. The Infrared Gas Analyzer (IRGA) Model LCpro-SD (ADC Bioscientific Ltd.) was used on open system from 8 to 11 AM for gas exchange analyses. AxDFFFA ascending curves of PAR (photosynthetically active radiation) at irradiation intensities of $0 ; 50 ; 200 ; 500 ; 700 ; 1,000$ and $1,200 \mu \mathrm{mol}$ photons $\mathrm{m}^{-2} \mathrm{~s}^{-1}$ were determined on the median region of the fourth fully expanded leaf of plants in all treatments. The values of maximum photosynthesis and respiration net in the dark were calculated by the adjustment of curve model as proposed by Lobo et al. (2013). Measurements of chlorophyll 
$a$ fluorescence was performed on the fourth fully expanded leaf pre-adapted to dark, according to the pulse method (SCHREIBER et al., 1994), using an OS5p+ Advanced Modulated Fluorometer (Opti-Sciences). The initial ( $\left.\mathrm{F}_{0}\right)$ and maximum $\left(\mathrm{F}_{\mathrm{m}}\right)$ fluorescence values were determined after induction of total darkness (60 minutes) with clips on the leaves. The potential quantum efficiency of photosystem II (PSII) was calculated as PSII $=\mathrm{F}_{\mathrm{v}} / \mathrm{F}_{\mathrm{m}}$. The maximum variable fluorescence emission $\left(\mathrm{F}_{\mathrm{v}}\right)$ was calculated as $\mathrm{F}_{\mathrm{v}}=\mathrm{F}_{\mathrm{m}}-\mathrm{F}_{0}$.

The data were evaluated by analysis of variance (ANOVA) followed by post-hoc Tukey test considering $p$ $\leq 5 \%$ as statistically significant. Analyses were calculated using Sisvar, version 5.6.

\section{RESULTS AND DISCUSSION}

The quantum efficiency of PSII was highly correlated $(p \leq 0.05)$ with the water regimes and cultivation periods (Figure 1). All treatments at 30 days showed the lowest values in relation to 60 and 90 days, especially on Drought treatment (70\% lowest than for 90 days), with an average of 0.2 , clearly indicating the low efficiency of the photosystems in the use of light. A decrease in $\mathrm{F}_{\mathrm{v}}$ / $\mathrm{F}_{\mathrm{m}}$ values is indicative of light-induced damage to PSII (values below 0.6) or other environmental stresses, such as water deficit (BOLHAR-NORDENKAMPF et al. 1989; MAXWELL and JOHNSON, 2000).

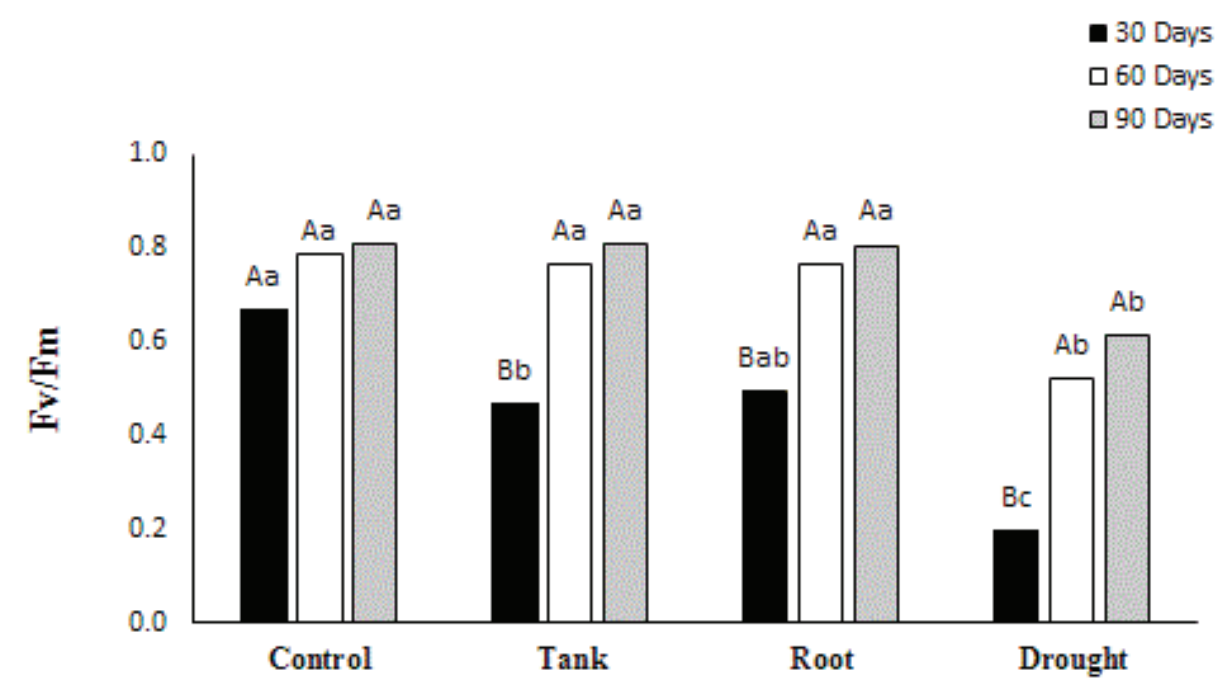

Figure 1. Maximum quantum yield of PSII $\left(\mathrm{F}_{\mathrm{v}} / \mathrm{F}_{\mathrm{m}}\right)$ of Guzmania lingulata submitted to different watering regimes at 30, 60 and 90 days of cultivation. Uppercase letters represent comparison among time intervals, and lowercase letters represent the comparison among treatments with Tukey test $(p \leq 0.05)$.

The lowest $\mathrm{F}_{\mathrm{v}} / \mathrm{F}_{\mathrm{m}}$ values were also observed at 30 days in the nutrition experiment (Figure 2), mainly when no $\mathrm{N}$ was added, with statistical differences between $\mathrm{N}$ concentrations supplied to root $(p \leq 0.05)$. The results of the two experiments suggested that microclimatic factors in the greenhouse also interfered with the energy conversion efficiency of PSII.

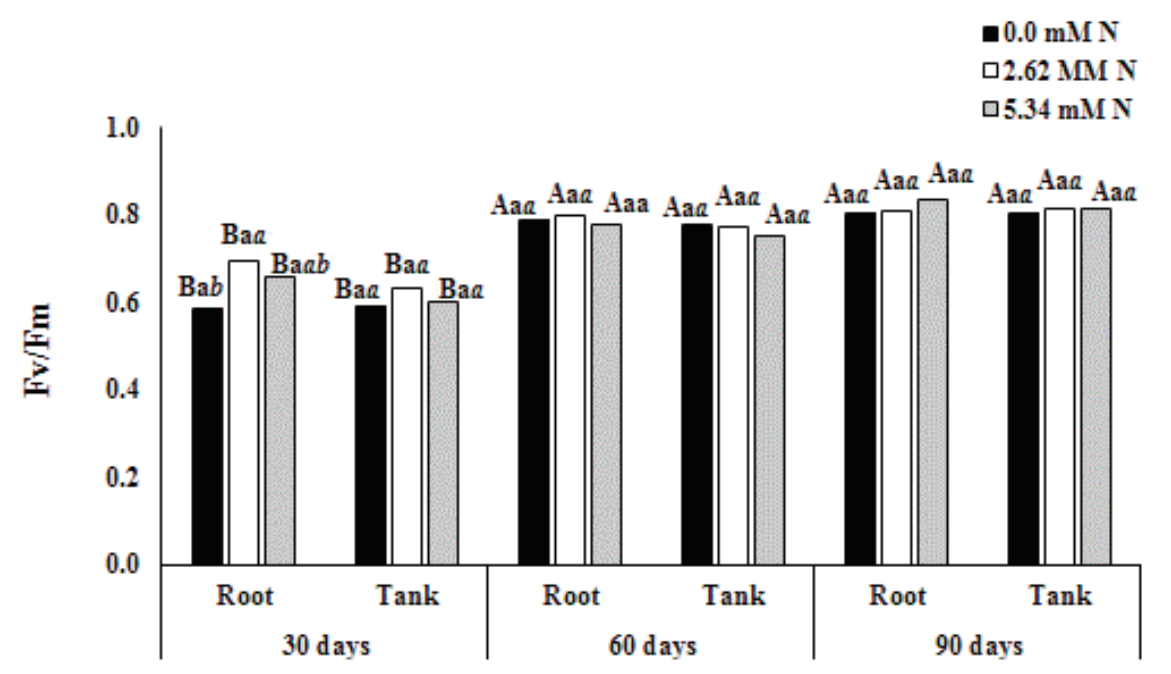

Figure 2. Maximum quantum yield of PSII $\left(\mathrm{F}_{\mathrm{v}} / \mathrm{F}_{\mathrm{m}}\right)$ of Guzmania lingulata fertilized with $0.00,2.62$ or 5.34 $\mathrm{mM} N$ in Tank or Root at 30, 60 and 90 days of cultivation. Uppercase letters represent comparison among time intervals, lowercase letters represent the comparison between organs, and italics letters comparison among $\mathrm{N}$ concentrations with Tukey test $(p \leq 0.05)$. 
During the experimental period, the highest temperature averages and lower relative air humidity occurred, which may have influenced the low $\mathrm{F}_{\mathrm{v}} / \mathrm{F}_{\mathrm{m}}$ values observed in the control treatments (Figures 1 and 2). $G$. lingulata requires an environment with high levels of humidity, being more tolerant to variations of photon flux density (PFD) values than to fluctuations on air humidity (SMITH, 1989).

The efficiency of PSII increased after 60 days with values around 0.8 for all treatments from the nutrition and hydration experiments, indicating absence of environmental stress (MATTOS, 2006). Although the drought treatment showed an increase of $43 \%$ of $\mathrm{F}_{\mathrm{v}} / \mathrm{F}_{\mathrm{m}}$ values from 30 to 60 days, values lower than 0.6 differed from the others treatments. Relative air humidity increased after 60 days, supporting the idea that microclimatic conditions influenced $\mathrm{F}_{\mathrm{v}} / \mathrm{F}_{\mathrm{m}}$ values. However, it is clear that water suspension was the main contributor to the adjustment of photosynthetic capacity and that both tank and root under this condition were able to guarantee water and nutritional status in order to maintain the photosynthetic process, notwithstanding water suspension.

$\mathrm{CO}_{2}$ assimilation values during the water experiment ranged from 0.8 to $2.0 \mu \mathrm{mol} \mathrm{CO} \mathrm{m}^{2} \mathrm{~s}^{-1}$ (Figure 3), which were dependent on the irrigation regime. Epiphytic bromeliads tend to have low atmospheric $\mathrm{CO}_{2}$ absorption rates, with values ranging from 2.0 to $3.0 \mu \mathrm{mol} \mathrm{m} \mathrm{m}^{-2} \mathrm{~s}^{-1}$, but for certain species, values around 0.8 to $1.5 \mu \mathrm{mol} \mathrm{m} \mathrm{m}^{-2} \mathrm{~s}^{-1}$ are common (MARTIN, 1994; GRIFFITHS and MAXWELL, 1999; MAXWELL, 2002).

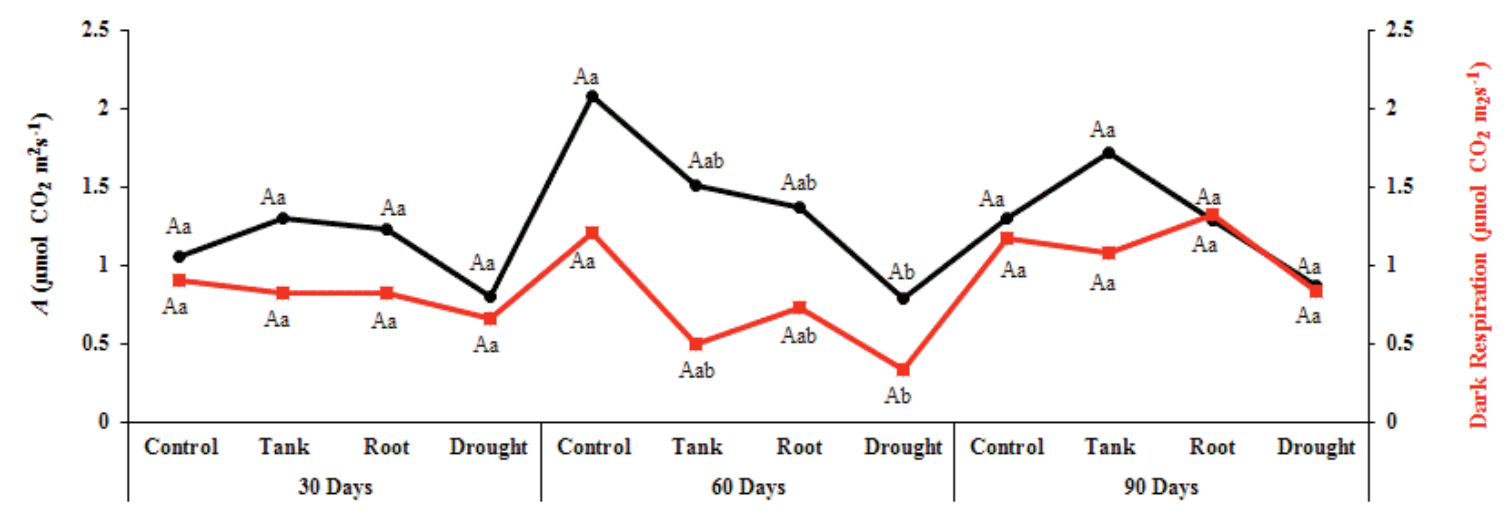

Figure 3. Net $\mathrm{CO}_{2}$ assimilation and Dark respiration of Guzmania lingulata submitted water regimes at 30, 60 and 90 days. Uppercase letters represent comparison among time intervals, and lowercase letters represent the comparison among treatments with Tukey test $(p \leq 0.05)$.

Low $A$ rates of $G$. lingulata when compared to tree species result from the presence of a high proportion of leaf parenchyma that stores water combined with low stomatal density, which allows water maintenance, but limits the fixation of atmospheric $\mathrm{CO}_{2}$. These features, together with other characteristics, such as high leaf longevity and low leaf hydraulic conductivity, account for reduced growth rates (MAXWELL, 2002; SIMONIN et al., 2012, NORTH et al., 2013).

During the water regime experiment, respiratory rates of G. lingulata ranged from 0.30 to $1.30 \mu \mathrm{mol} \mathrm{m} \mathrm{m}^{-2} \mathrm{~s}^{-1}$ (Figure 3). However, all values were higher than photosynthetic assimilation, thus having a positive carbon balance. All treatments showed the highest respiratory rate averages at 90 days, which is compatible with plant growth on Control, Tank and Root treatments during the experiment (data not shown) and the increase of water deficit responses in the Drought treatment. In both regimes, we saw an increase of energy demand, although it was necessary to restock ATP (ATKIN and MACHEREL, 2009; GIMENO et al., 2010).
Drought treatment showed the lowest mean values of gas exchange; however, statistical differences between the hydrated treatments and the water suspension treatment were only observed at 60 days, most likely owing to high data variability. Therefore, since a larger number of replicates are necessary, gas exchange analysis is not a good parameter to compare treatments, but it is a suitable tool to characterize the general patterns of $G$. lingulata responses to stress. The scatter of individual readings in studies with bromeliads is due to variability in plant behavior and heterogeneity of gas exchange and other parameters not only occurs along the length of a given leaf but also between individual leaves (LÜTTGE et al., 1986). Thus, the chlorophyll $a$ fluorescence technique was more efficient in providing information about $G$. lingulata patterns of photosynthetic capacity, and it was a good tool with which to compare responses between treatments.

The nutrition experiment (Figure 4) showed an increase of nearly $60 \%$ of $A$ values from 30 to 90 days, considering 2.62 and $5.34 \mathrm{mM} \mathrm{N}$ treatments in Tank or Root, with statistical differences between treatments. 


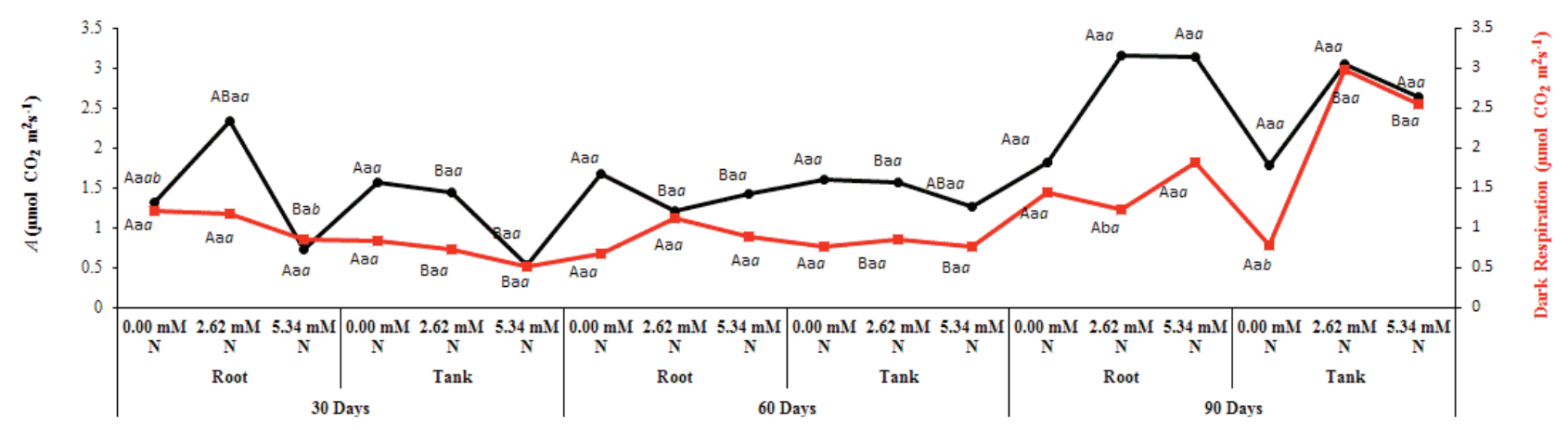

Figure 4. Net $\mathrm{CO}_{2}$ assimilation and Dark respiration of Guzmania lingulata fertilized with 0.00, 2.62 or $5.34 \mathrm{mM} \mathrm{N}$ in Tank or Root at 30, 60 and 90 days. Uppercase letters represent comparison among time intervals, lowercase letters represent the comparison between organs and italics letters comparison among $\mathrm{N}$ concentrations with Tukey test $(p \leq 0.05)$.

The respiratory rates also increased during experimentation, especially in plants fertilized into the tank with $2.62 \mathrm{mM} \mathrm{N}$. These results demonstrate that $\mathrm{N}$ fertilization in tank or roots is advantageous for $G$. lingulata. Especially, since the root system showed adequate nutrient uptake, this strategy should be integrated into horticultural fertilization management programs. In addition, G. lingulata increases photosynthetic capacity and maintains a positive carbon balance with regular exposure to $\mathrm{N}$ fertilization. However, high concentrations of $\mathrm{N}$ do not increase the biological responses and may, therefore, be attributed to "luxury consumption" since epiphytic species in their natural environment are generally exposed to low concentrations of nutrients (ZOTZ and ASSHOFF, 2010). Nutrient uptake capacities by bromeliads are normally tuned towards the capture of short pulses, though nutrients not needed for current metabolism, and such as a combination of high uptake of nutrient and slow growth, frequently leads to an accumulation of reserves (BENZING, 1973; BENZING and RENFROW, 1974; WINKLER and ZOTZ, 2009).

\section{CONCLUSIONS}

The ornamental G. lingulata is benefited by the supply of water and nutrients to the root system. Although the parameters of chlorophyll $a$ fluorescence and gas exchange are not often used in ornamental horticulture studies, these techniques can provide important information about growth, development and stress responses from ornamental plants and can be incorporated as a tool for bromeliad horticulture.

\section{ACKNOWLEDGMENTS}

The authors thank CNPq (Conselho Nacional de Desenvolvimento Científico e Tecnológico) for the financial support (proc. 455929/2014-9) and for the productivity grant (306140/2012-8) of A.R.T.

\section{AUTHORS CONTRIBUTIONS}

KGS: conception and design of the research, obtaining data, analyze and interpretation of data, statistical analysis, write and critically analyses of manuscript. EAS: analyze and interpretation of data, statistical analysis, write and critically analyses of manuscript. MLF: analyze and interpretation of data, statistical analysis, write and critically analyses of manuscript. SK: analyze and interpretation of data, statistical analysis, write and critically analyses of manuscript. PBC: analyze and interpretation of data, statistical analysis, write and critically analyses of manuscript. ARS: conception and design of the research, obtaining data, analyze and interpretation of data, statistical analysis, write and critically analyses of manuscript and financial and obtaining funding.

\section{REFERENCES}

ANDRADE, F.S.A.; DEMATTÊ, M.E.S.P. Estudo sobre produção e comercialização de bromélias nas regiões Sul e Sudeste do Brasil. Revista Brasileira de Horticultura Ornamental, v.5, p.97-110, 1999.

ATKIN, O.K.; MACHEREL, D. The crucial role of plant mitochondria in orchestrating drought tolerance. Annals of Botany, v.103, n.4, p.581-597, 2009. DOI: <http://dx.doi. org/10.1093/aob/mcn094>

BENZING, D.H. Mineral nutrition and related phenomena in Bromeliaceae and Orchidaceae. The Quarterly Review of Biology, v.48, n.2, p.277-290, 1973. DOI: < https://doi. org/10.1086/407590>

BENZING, D.H.; RENFROW, A. The mineral nutrition of Bromeliaceae. Botanical Gazette, v.135, n.4, p.281-288, 1974. DOI: <https://doi.org/10.1086/336762> 
BOLHAR-NORDENKAMPF, H.R.; LONG, S.P.; BAKER, N.R.; OQUIST, G.; SCHREIBER, U.L.E.G.; LECHNER, E.G. Chlorophyll fluorescence as a probe of the photosynthetic competence of leaves in the field: a review of current instrumentation. Functional Ecology, v.3, n.4, p.497-514, 1989. DOI: <http://dx.doi. org/10.2307/2389624>

CACH-PÉREZ, M.J.;ANDRADE, J.L.; REYES-GARCÍA, C. La susceptibilidad de las bromeliáceas epífitas al cambio climático. Botanical Sciences, v.92, n.2, p.157-168, 2014. DOI: <http://dx.doi.org/10.17129/botsci.55>

GIMENO, T.E.; SOMMERVILLE, K.E.; VALLADARES, F.; ATKIN, O.K. Homeostasis of respiration under drought and its important consequences for foliar carbon balance in a drier climate: insights from two contrasting Acacia species. Functional Plant Biology, v.37, n.4, p.323-333, 2010. DOI: < https://doi.org/10.1071/FP09228>

GRIFFITHS, H.; MAXWELL, K. In memory of C.S. Pittendrigh: Does exposure in forest canopies relate to photoprotective strategies in epiphytic bromeliads? Functional Ecology, v.13, n.1, p.15-23, 1999. DOI: $<$ https://doi.org/10.1046/j.1365-2435.1999.00291.x>

HOAGLAND, D.R.; ARNON, D.I. The water-culture method for growing plants without soil. Circular 347. Berkeley: California Agricultural Experiment Station, 1950. 32p.

KRAUSE, G.H.; WEIS, E. Chlorophyll fluorescence and photosynthesis: the basics. Annual Review of Plant Biology, v.42, n.1, p.313-349, 1991. DOI: <https://doi. org/10.1146/annurev.pp.42.060191.001525>

LOBO, F.D.A.; DE BARROS, M.P.; DALMAGRO, H.J.; DALMOLIN, Â.C.; PEREIRA, W.E.; DE SOUZA, É.C.; ORTÍZ, C.R. Fitting net photosynthetic light-response curves with Microsoft Excel-a critical look at the models. Photosynthetica, v.51, n.3, p.445-456, 2013. DOI: $<$ https:// doi.org/10.1007/s11099-013-0045-y>

LONG, S.P.; BERNACCHI, C.J. Gas exchange measurements, what can they tell us about the underlying limitations to photosynthesis? Procedures and sources of error. Journal of Experimental Botany, v.54, n.392, p.2393-2401, 2003. DOI: $<$ https://doi.org/10.1093/jxb/erg262>

LÜTTGE, U.; STIMMEL, K.H.; SMITH, J.A.C.; GRIFFITHS, H. Comparative ecophysiology of CAM and C3 bromeliads. II. Field measurements of gas exchange of CAM bromeliads in the humid tropics. Plant, Cell $\boldsymbol{\&}$ Environment, v.9, n.5, p.377-383, 1986. DOI: <https:// doi.org/10.1111/j.1365-3040.1986.tb01751.x

MARTIN, C.E. Physiological ecology of the Bromeliaceae. Botanical Review, v.60, n.1, p. 1-82, 1994. DOI: <https:// doi.org/10.1007/BF02856593>
MATTOS, E.A. O estudo da fluorescência da clorofila e a detecção de estresses ambientais em plantas. In: PRADO, C.H.B.A.; CASALI, C.A. Fisiologia Vegetal: práticas em relações hídricas, fotossíntese e nutrição mineral. São Paulo: Editora Manole, 2006. p.255-266.

MAXWELL, K. Resistance is useful: diurnal patterns of photosynthesis in C3 and crassulacean acid metabolism epiphytic bromeliads. Functional Plant Biology, v.29, n.6, p.679-687, 2002. DOI: <https://doi.org/10.1071/PP01193>

MAXWELL, K.; JOHNSON, G. N. Chlorophyll fluorescence- $a$ practical guide. Journal of Experimental Botany, v.51, n.345, p.659-668, 2000. DOI: <https://doi. org/10.1093/jexbot/51.345.659>

NORTH, G.B.;LYNCH, F.H.;MAHARAJ,F.D.;PHILLIPS, C.A.; WOODSIDE, W.T. Leaf hydraulic conductance for a tank bromeliad: axial and radial pathways for moving and conserving water. Frontiers in Plant Science, v.4, p.78, 2013. DOI: <https://doi.org/10.3389/fpls.2013.00078>

PITA, P.B.; MENEZES, N.L. Anatomia da raiz de espécies de Dyckia Schult. f. e Encholirium Mart. ex Schult. \& Schult. f. (Bromeliaceae, Pitcairnioideae) da Serra do Cipó (Minas Gerais, Brasil), com especial referência ao velame. Revista Brasileira de Botânica, v.25, n.1, p.25-34, 2002. DOI: $<$ http://dx.doi.org/10.1590/S0100-84042002000100005>

PROENÇA, S.L.; SAJO, M.G. Rhizome and root anatomy of 14 species of Bromeliaceae. Rodriguésia, v.59, n.1, p.113-128, 2008.

RAMOS TAMAYO, P.; WEISS, O.; SANCHEZ MOREIRAS, A. Gas exchange techniques in photosynthesis and respiration. Infrared gas analyzer. In: REIGOSA ROGER, M.J. Handbook of plant ecophysiology techniques. Dordrecht, Boston: Kluwer Academic Publishers, 2001. 452p.

SCHREIBER, U.; BILGER, W.; NEUBAUER, C. Chlorophyll fluorescence as a nonintrusive indicator for rapid assessment of in vivo photosynthesis. Ecological Studies, v.100, p.49-70, 1994. DOI: <https://doi. org/10.1007/978-3-642-79354-7_3>

SEGECIN, S.; SCATENA, V.L. Morfoanatomia de rizomas e raízes de Tillandsia L. (Bromeliaceae) dos Campos Gerais, PR, Brasil. Acta Botanica Brasilica, v.18, n.2, p.253-260. 2004. DOI: <http://dx.doi.org/10.1590/S010233062004000200005>

SHARKEY, T. D. What gas exchange data can tell us about photosynthesis. Plant, Cell \& Environment, v.39, n.6, p.1161-1163, 2016. DOI: <http://dx.doi.org/10.1111/ pce. $12641>$ 
SIMONIN, K.A.; LIMM, E.B.; DAWSON, T.E. Hydraulic conductance of leaves correlates with leaf life span: implications for life-time carbon gain. New Phytologist, v.193, n.4, p.939-947, 2012. DOI: <http://dx.doi.org/10.11 11/j.1469-8137.2011.04014.x>

SMITH, J.A.C. Epiphytic Bromeliads. In: LUTTGE, V. (ed.). Vascular plants as epiphytes- ecological studies. Berlin, Heidelberg, New York: Springer, 1989. pp.109-138.

SOUZA, V.C.; LORENZI, H. Botânica Sistemática - Guia ilustrado para identificação das famílias Fanerógamas nativas e exóticas do Brasil, baseado em APGII. Nova Odessa: Instituto Plantarum de estudos da Flora, 2000. 274p.

TAIZ, L.; ZEIGER, E. 2006. Fisiologia Vegetal. Porto Alegre: Artmed, 2006. 722p.
WINKLER, U.; ZOTZ, G. Highly efficient uptake of phosphorus in epiphytic bromeliads. Annals of Botany, v.103, n.3, p.477-484, 2009. DOI: <https://doi.org/10.1093/ aob/men231>

WOODRUFF, D.R.; MEINZER, F.C.; MARIAS, D.E.; SEVANTO, S.; JENKINS, M.W.; MCDOWELL, N.G. Linking nonstructural carbohydrate dynamics to gas exchange and leaf hydraulic behavior in Pinus edulis and Juniperus monosperma. New Phytologist, v.206, n.1, p.411-421, 2015. DOI: <http://dx.doi.org/10.1111/ nph.13170>

ZOTZ, G.; ASSHOFF, R. Growth in epiphytic bromeliads: response to the relative supply of phosphorus and nitrogen. Plant Biology, v.12, n.1, p.108-113, 2010. DOI: <http:// dx.doi.org/10.1111/j.1438-8677.2009.00216.x> 